\title{
LEGAL ANALYSIS OF THE POSITION OF VILLAGE OWNED BUSINESS ENTITIES AS A LEGAL ENTITY AFTER THE ENTRY OF LAW NUMBER 11 YEAR 2020 CONCERNING WORK CREATION
}

\author{
Alting Husen, Suwarti, Lecturers \\ Faculty of Law and Postgraduate Law Sciences, Unkhair Ternate, Indonesia \\ *E-mail: husenalting@yahoo.com
}

\begin{abstract}
This study aims to analyze the existence of Village-Owned Enterprises (VOBEa) as legal entities after the enactment of Law Number 11 of 2020 concerning Job Creation and examine whether VOBEA which have been domiciled as legal entities after the enactment of Law Number 11 of 2020 concerning Job Creation carry out the functions of a public legal entity or a private legal entity. This research is a normative legal research that is descriptive. The approach used in this research is the statutory approach (statute approach), conceptual approach (conceptual approach) and contains a case approach that is studied to support research. The results of the study show that the existence of village-owned enterprises (VOBEA) as legal entities after the enactment of Law Number 11 of 2020 concerning Job Creation has provided clarity and affirmation of the legal entity status of VOBEa Article 117 of the Job Creation Law changing the provisions of Article 1 point 6 of the Village Law., which is explicitly stated that "Village-Owned Enterprises, hereinafter referred to as VOBEA, are legal entities established by villages and/or together with villages to manage businesses, utilize assets, develop investment and productivity, provide services, and/or providing other types of business for the maximum welfare of the Village community. As for the status of legal entities after the enactment of law number 11 of 2020 concerning job creation in carrying out the functions of public legal entities and private legal entities, it implicitly means that the construction of VOBEA as a unique business entity and has special village characteristics. Thus, VOBEA can be classified as legal entities with public functions, namely VOBEA as functional public legal entities that carry out both public and private legal functions.
\end{abstract}

\section{KEY WORDS}

Village-owned enterprise (VIBE), Ciptaker Law, public function.

Regional autonomy as a concept that gives more parts to the regions to channel all regional affairs and interests so that they can be managed independently according to the different potentials of each region. This means that even a village on a smaller scale has considerable authority in managing all affairs and needs in accordance with what is needed in the area. Thus, the ethical legitimacy of Law no. 6 of 2014 concerning Villages wants to bring about very basic changes in the order of village governance. After the enactment of Law Number 6 of 2014 concerning Villages, it means that villages are given a great opportunity to manage their own governance and implementation of development to improve the welfare and quality of life of rural communities.

Villages have sources of income consisting of Village Original Income (VOI), revenue sharing from district taxes and levies, part of the central and regional financial balance funds received by the district, assistance from the government and local governments as well as grants and donations from third parties. One of the sources of VOI that can be managed by the village government is to establish a Village Owned Enterprise (VOE), which is a village economic institution/body that is formed and owned by the village government and the community, managed economically independently and professionally.

VOBEA is a business institution engaged in the management of village economic assets and resources within the framework of empowering rural communities. The VOBEA arrangement is regulated in Article 213 paragraph (1) of Law No. 32 of 2004, that Villages can establish Village-Owned Enterprises in accordance with the needs and potential of the 
village. In VFAition, it is also regulated in Government Regulation Number 72 of 2005 concerning Villages, which regulates VOBEA, namely Articles 78-81, Fifth Part concerning Village-Owned Enterprises, and the last is Minister of Home Affairs Regulation Number 39 of 2010 concerning Business Entities. Village Owned.

Problems that arise in village development through the establishment of VOBEA arise when the formation of VOBEA is only oriented in terms of quantity. Whereas the funds allocated to the village are around Rp., 20 Trillion which is divided among 74 thousand villages, ${ }^{1}$ so that each village will receive $\mathrm{Rp}$. 240 Millions not including the Village Fund Allocation (VFA) from the district, while the number of VOBEA in 2017 reached 18,446 units.

As one of the economic institutions operating in rural areas, VOBEa must be different from other economic institutions in general, as stated in the elucidation in Article 87 of Law no. 6 of 2014 concerning villages; specifically VOE cannot be equated with legal entities such as limited liability companies, CV, or cooperatives. Therefore, VOE is a business entity characterized by a Village which in carrying out its activities in addition to assisting the implementation of Village Government, also to meet the needs of the Village community.

With the presence of VOBEA, it is hoped that the village will become more independent and the community will be more prosperous. However, considering that VOBEA is still a new thing in its existence, it is inevitable that in practice, several obstacles arise that are related to the process of its formation.

First, there is no legal basis for the existence of VOBEA in the village. Although it is implied that the spirit to institutionalize VOBEA has been mandated and underpinned by the issuance of Law Number 8 of 2005 concerning amendments to Law Number 32 of 2004 concerning Regional Government, as mandated in Chapter VII section Fifth which states that Village Governments can establish Business Entities Village property in accordance with the needs and potential of the village in the hope of increasing the income of the community and village. As a follow-up to the implementation of the establishment of VOBEA, then based on article 78 of PP 72 of 2005 concerning Villages, it is explained that the Regency/City Government needs to stipulate a Regional Regulation on Procedures for the Establishment and Management of Village-Owned Enterprises (VOBEA).

Second, the legality of the proper form of legal entity turned out to be a bigger problem for the establishment of VOBEA. Even in cases that often occur, VOBEA does not use the form of a legal entity, but "only" in the form of a business entity that is not a legal entity. Whereas the provisions of article 78 paragraph (3) of Government Regulation Number 72 of 2005 concerning Villages state that the Form of Village-Owned Enterprises must be a legal entity. Furthermore, it is increasingly becoming a polemic of the Job Creation Law in article 117 which revokes article 87 of Law no. 6 of 2014 Village Law.

Then further regulation is regulated through Government Regulation no. 11 of 2021 concerning VOE revoking articles 132-142, furthermore it is also regulated through PP Number 43 of 2014 concerning Implementing Regulations of Law Number 6 of 2014 concerning Villages stating that Village-Owned Enterprises, hereinafter referred to as VOE, are legal entities established by villages. If the first problem surrounding the formation of VOBEA can be overcome by revising the Perda that is not yet appropriate, then this second problem will not stop with revising the umbrella Perda, but must fix the formation of the VOBEA legal entity in the form of the right legal entity, whether it performs the functions of a public legal entity. or the function of a private legal entity.

Starting from the background and identification of the problems described above, several problems are formulated as follows:

- How is the Existence of Village Owned Enterprises (BUMDDes) as Legal Entities after the Enactment of Law Number 11 of 2020 concerning Job Creation?

- Does VOBEA, which has been domiciled as a legal entity after the enactment of Law Number 11 of 2020 concerning Job Creation, performs the functions of a public legal entity or a private legal entity?

\footnotetext{
${ }^{1}$ Detik News, "Tingkatkan Perekonomian Desa, 74 Ribu Desa Bakal Terima Dana Rp 1,4 Miliar", www.news.detik.com Diakses Pada 26 Maret 2021.
} 
General Purpose. By knowing the conditions for a business entity to have a legal entity position after the enactment of Law Number 11 of 2020 focusing on the existence of VOBEA as a legal entity.

Special Purpose. The special benefit of this research is that it becomes a recommendation material for stakeholders and the community.

\section{LITERATURE REVIEW}

Legal Entity is a translation of legal terms, namely rechtspersoon (Dutch), persona moralis (Latin), and legal persons (English). The term rechtspersoon is the opposite of natuurlijk person (human). In the Civil Code of the Civil Code, the terms rechtspersoon and legal entities are not found, nor are there general regulations governing rechtspersoons and legal entities in full.

In general, the division of business entities in conducting business activities in accordance with the provisions of the legislation in force in Indonesia is grouped into 2 (two) major parts, namely: legal entities and non-legal entities. Legal entities, for example, include: limited liability companies, cooperatives, foundations, state-owned enterprises, corporations, public companies, and public companies. Business entities that are not legal entities include individual businesses, civil partnerships (maatschap), firms, limited partnerships (CV). It is necessary to know the relevance of the division of the 2 (two) groups in relation to the introduction of the obligations and responsibilities of the founders/shareholders. The grouping of the two business entities can be seen with a significant difference.

Subject and capital. Since its establishment was ratified, the legal subject of the legal entity is himself/herself as the personification of the person as a legal entity. Therefore, he himself has been recognized as a separate legal entity from the founders/shareholders. In carrying out its actions, a legal entity is represented by an appointed management/director in accordance with the deed of establishment/statutes of association. Meanwhile, the legal subject in a business entity that is not a legal entity is attached to the founder or management, thus the business entity is not a legal subject that stands alone outside the founder/management. In carrying out legal relations with third parties, business entities that are not legal entities are represented by the founders who also act as administrators.

This legal entity has rights and obligations, while the non-legal entity does not. As a legal consequence, a third party that has an engagement can only sue the founder/or its management, and not the business entity as a legal entity. Regarding assets (capital) in a legal entity, it is separated from the assets of the founders/management, while assets in a non-legal entity business entity are mixed with the assets/wealth of the founders/management. In addition, a business entity with a legal entity can be sued and sued, while a business entity that is not a legal entity cannot, but can be addressed to the founder/active management because it is the active founder/manager who indirectly has a legal relationship.

Establishment procedure. The establishment of a business entity as a legal entity absolutely must have approval from the government against the deed of establishment and articles of association. As an illustration, the deed of establishment of a limited liability company is approved by the Minister of Law and Human Rights (Article 7 paragraph (4) of the Limited Liability Company Law), while the establishment of a law firm is only established under a notarial deed and then registered at the Registrar of the District Court within its jurisdiction, firm domiciled (Article 23 of the Commercial Code).

Wealth and accountability. In a legal entity, the liability of the founder/shareholder for the business entity's engagement to a third party is only limited to the capital (inbreng) that is included in the business entity. Meanwhile, for business entities that are not legal entities, the liability will reach the founder's personal assets, aka there are no restrictions. In the event of bankruptcy (bankruptcy) or in liquidation, the assets that are cleared in a legal entity that are cleared are only registered assets/capital, while in a legal entity that is not a legal entity, the settlement is carried out on all of their assets up to their personal assets. 
The law is the business entity itself, because it has become a legal entity which is also a legal subject in addition to humans. In this business entity, the assets separate from the personal assets of the management/members. As a result, if the company goes bankrupt, only the company's assets will be confiscated (personal assets of the management/members remain free from confiscation). Meanwhile, the characteristics of a business entity that is not a legal entity is that its legal subjects are the people who are its administrators, so it is not the business entity itself because it is not a law so that it cannot become a legal subject. In this business entity, the company's assets are united with the personal assets of the management/members. As a result, if the company goes bankrupt, the personal assets of the management/members will also be confiscated in addition to the company assets.

Practically, VOE occurs because the legal rules of Article 87 of Law Number 6 of 2014 concerning Villages legitimize VOE legal entities which specifically cannot be equated with private legal entities (CV, PT, and Cooperatives). Legal logic provides the idea of correlation between categories to clarify the reasoning of public legal entities characterized by Village (VOE) and private legal entities (CV, PT, cooperative).

1. Private legal entities (CV, PT, and Cooperatives) are based on individual or group personalities (Gesammtpersönlichkeit; Jerman);

2. Public legal entity characterized by Village (VOE) based on collective-personality (Gesammtpersönlichkeit; Jerman);

3. The establishment of private legal entities (CV, PT, Cooperative) aims to serve the interests of these individuals and community groups;

4. The establishment of a public legal entity characterized by a Village (VOE) aims to assist the implementation of Village Government and meet the needs of the Village community;

5. The logical relationship between the personality of a legal entity (point 1 and point 2) and the purpose of its establishment (point 3 and point 4) is a sub-alternation. Private legal entities (CV, PT, Cooperatives) exist to serve the interests of individuals or groups, while VOE legal entities exist to assist the administration of Village Government and meet the needs of the Village community;

6. Personality logical relationship between private legal entities (point 1) and VOE legal entities (point 2) is contradictory. Private legal entities (CV, PT, Cooperative) do not have the collective personality as found in VOE legal entities, while VOE legal entities do not have individual and group personalities as found in private legal entities (CV, PT, Cooperatives). With this reasoning, a private legal entity (CV, PT, Cooperative) cannot be called a VOE, while a VOE cannot be called a private legal entity (CV, PT, Cooperative);

7. The logical relationship between the personality of a private legal entity (point 1) and the purpose of establishing a VOE legal entity (point 4) is contradictory. Likewise with the same reasoning on the personality of a VOE legal entity (point 2) and the purpose of establishing a private legal entity (point 3).

The personality of private legal entity groups may not exist to assist the administration of Village Government and meet the needs of the Village community. The collective personality of the VOE legal entity cannot exist only to serve the interests of certain individuals and community groups. The consequence of the logical relationship between VOE public legal entities characterized by Villages that are contradictory and contradictory to private legal entities is to determine strategic actions taken by the System, both state power and market power.

The supra-village government has the authority to carry out administrative verification actions against VOE in relation to the substance of the regulations in the Village that legitimize it. This aims to strengthen evidence-based legal reasons that legitimize the authority of the government, provincial regional governments, and village governments to provide grants and/or access to capital, technical assistance and access to markets, and policies that prioritize protection. law against VOE in the management of natural resources in the Village. Therefore, the regulations issued by the supra-Village government compile 
criteria in the rules of procedure to ensure the real existence of VOBEa as a public legal entity characterized by a Village ${ }^{2}$ :

- Minutes of the Village Deliberation Results that agreed on the establishment of VOE;

- Village Regulation regarding the establishment of VOE;

- Village Head Decree on VOE's Articles of Association and Bylaws;

- Village Head Decision on VOE Management Structure;

- Decision of the Village Head regarding the Status of Utilization of Village Assets Managed by Village Owned Enterprises, or the use of Village assets by VOE;

- VOE as a Public Legal Entity with Village Characteristics is required to provide information on its performance openly to the public regarding the use of Village Funds, Village assets, and the results of strategic partnership collaborations for the development and empowerment of Village communities.

Based on the description above, the form of a legal entity business unit that can be owned by VOBEA is a Limited Liability Company and Cooperative. Another form of business entity that can also have the status of a legal entity, namely the Foundation, the author will not describe here, because the foundation is a legal entity that is social in nature, not looking for profit. The establishment of VOBEA is clear, to seek profit, namely increasing Village Original Income and the welfare of the village community.

The procedures and procedures for establishing VOBEA are currently regulated in the Regulation of the Minister of Villages, Development of Disadvantaged Regions, and Transmigration of the Republic of Indonesia Number 4 of 2015 concerning the establishment, management and management, and dissolution of village-owned enterprises. From the Permendes it can be concluded that the steps that must be taken to establish VOBEA are:

1. Village Deliberations (Article 5 paragraph (1). In the Village Deliberations that need to be agreed upon, among others:

- Management organization VOBEA;

- VOBEA working capital;

- VOBEA Anggarans Articles of Association and Bylaws.

2. The Village Government and the Village Consultative Body (BPD) stipulate a Village Regulation concerning the Establishment of VOBEA. The results of the Village Deliberation agreement as referred to in paragraph (1) serve as guidelines for the Village Government and the Village Consultative Body to establish Village Regulations concerning the Establishment of VOBEA.

3. VOBEA establishes business units/business institutions. Business Units that can be formed by VOBEA are (article 8):

- Limited company;

- Microfinance Institutions with a VOBEA share of 60 (sixty) percent.

If we look at the provisions of Article 4, Law Number 1 of 2013 concerning Microfinance Institutions, the law requires that the establishment of MFIs must at least meet the requirements:

1. Form of legal entity: Cooperative or PT whose shares are at least $60 \%$ (sixty percent) owned by VOBEA and Ownership of every Indonesian citizen over the shares of a Limited Liability Company as referred to in paragraph (3) letter a is at most $20 \%$ (twenty percent);

2. Capital;

3. Obtain a business license whose procedure is regulated in this Law.

In the event that VOBEA does not have business units that are legal entities, the VOBEA organizational form is based on the Village Regulation concerning the Establishment of VOBEA. From the description above, it can be concluded that to form a VOBEA, it is sufficient for the village government to issue a village regulation concerning the formation of a VOBEA. With the village regulation, VOBEA already has the status of a legal entity and can carry out legal actions like humans. this is based on Article 1653 of the Civil Code Jo.

\footnotetext{
${ }^{2}$ Anom Surya Putra, Ketua Umum Perkumpulan Jaringan Komunikasi (Jarkom) Desa, "VOBEa Bukan Badan Hukum Privat", https://www.desapedia.id/vobea-bukan-badan-hukum-privat/, (Diakses Pada Tanggal 8 Juli 2021)
} 
Permendes No. 4 of 2015, where local government organizations are legal entities and local governments can form legal entities.

However, in generally accepted practice, a good business entity is one that focuses on one business. This is important to do to control the business being run. there are business fields that have big profits but there are also those that can lose. If the business entity is separated, it will be clear which line of business is burdening the VOBEA, which then needs to be considered for immediate removal.

If the village government in establishing VOBEA only comes in the form of a village regulation, VOBEA will find it difficult to carry out business activities that require a large enough capital, besides that community participation will be difficult to realize, because it gives the impression that VOBEA is an extension of the village government. Even in banking practice, VOBEA, which was established with the Minister of Village Regulation, is difficult to accept in economic traffic. Banks will find it difficult if there are VOBEA problems and want to confiscate or hold VOBEA management accountable, in this condition the price of VOBEA assets is often an integral part of the village government assets. For this reason, VOBEAs that are established need to form business units as mandated by Article 8 Permendes No. 4 Year 2015.

Alternative Forms of the Right Legal Entity in Establishing VIBE. It is required in article 78 paragraph (3) of Government Regulation Number 72 of 2005 concerning Villages, that the Form of Village-Owned Enterprises must be a legal entity. So the appropriate form of legal entity in establishing VOBEA includes: Village Public Company (VPC), or Limited Liability Company (Village Company).

- Village Public Company (VPC):

This form of VPC is a form of VOBEA legal entity which was adopted from the form of a SOES legal entity, namely Perum. As regulated in Article 1 point 4 of Law Number 19 of 2003 concerning SOES, Public Company, hereinafter referred to as Perum, is a SOES whose entire capital is owned by the state and is not divided into shares, which aims for public benefit in the form of providing goods and/or services. of high quality and at the same time pursuing profit based on the principles of corporate management. For VOBEA, it is very appropriate if the Public Company or Perum is then called the Village Public Company (VPC). VPC as a form of legal entity VOBEA whose capital is wholly owned by the Village Government which is village wealth which is separated and stipulated by Village Regulation, then as a form of Perum in SOES, VPC capital is also not divided into shares, and VPC aims for public benefit in the form of providing goods and services. / or services of high quality and at the same time pursuing profit based on the principles of corporate management.

The composition of the organs of Perum according to Article 37 of Law no. 19 of 2003 concerning SOES is the Minister, the Board of Directors and the Supervisory Board. However, regarding the VOBEA organ, it has been specifically regulated in articles 6 and 7 of the Regulation of the Minister of Home Affairs Number 39 of 2010 concerning Village-Owned Enterprises, namely:

Article 6:

"The VOBEA management organization is separate from the village government organization."

Article7:

"(1) The VOBEA management organization as referred to in Article 6 shall at least consist of: (a) advisors or commissioners; and (b) operational executives or directors;

(2)The advisor or commissioner as referred to in paragraph (1) letter $a$, is held by the Village Head;

(3)The operational executive or board of directors as referred to in paragraph (1) letter b, consists of: (a) the director or manager; and (b) head of business unit".

- Village Limited Liability Company (VLLC):

This form of Limited Liability Company is a form of VOBEA legal entity which was adopted from the form of a SOES legal entity, namely Persero. As regulated in Article 1 point 2 of Law Number 19 of 2003 concerning SOES, a Limited Liability Company, hereinafter referred to as Persero, is a SOES in the form of a limited liability company whose capital is 
divided into shares of which all or at least $51 \%$ (fifty one percent) of the shares owned by the Republic of Indonesia whose main purpose is to pursue profit. Article 11 of Law no. 19 of 2003 states that the Persero applies all the provisions and principles that apply to limited liability companies as regulated in Law no. 1 of 1995 concerning Limited Liability Companies (now Law No. 40 of 2007 concerning Limited Liability Companies). So against VOBEA in the form of a Limited Liability Company, all provisions and principles that apply to limited liability companies as regulated in Law no. 40 of 2007 concerning Limited Liability Companies (LLC).

A limited liability company must have aims and objectives as well as business activities that do not conflict with the provisions of laws and regulations, public order and/or morality, as regulated in Article 2 of the Company Law. The purposes and objectives and business activities of the Limited Liability Company must be stated in its Articles of Association, as stated in Article 18 of the Company Law.

The types of business activities of the Village Company are adjusted to the economic potential of the Village community and have good business prospects. The types of VOBEA activities as regulated in articles 12 and 13 of the Regulation of the Minister of Home Affairs Number 39 of 2010 concerning Village-Owned Enterprises can be in the form of: a) services, b) distribution of nine basic commodities, c) trade in agricultural products, and/or d) small and household industries The selection of the types of VOBEA activities is grouped into Village Business Units, and the selection is carried out through village meetings.

\section{METHODS OF RESEARCH}

This research is a normative legal research, where the concept of normative legal research or library research is research that examines document studies with a case approach, which uses various secondary data such as legislation, court decisions, legal theory, and can be in the form of opinions of scholars.

The approach used in this research is the statutory approach (statute approach) and the conceptual approach (conceptual approach) and includes the case approach under study to support the research. The statutory approach is an approach that is carried out by examining all laws and regulations related to the legal issues being handled. This conceptual approach is also carried out when the relevant laws and regulations do not or do not regulate the problem at hand.

To build strong legal arguments, not only based on the provisions of the legislation but also moving on to a conceptual approach in the form of scholarly views and legal doctrines contained in books (treatises) and court decisions. For this reason, a statutory and conceptual approach is used to answer legal issues and build a strong legal argument in this research. ${ }^{3}$

The types and sources of data used as material for analysis consist of:

- Secondary data, namely data obtained from documents relating to the problem under study;

- Tertiary data, namely data obtained from compilation of primary and secondary data.

The legal material collection techniques used by researchers are as follows:

- Literature Study, namely a method of collecting legal materials by conducting a search on library materials, namely collecting and reviewing laws and regulations, legal books, opinions of legal scholars. As well as the results of previous research related to the research problem under study, namely in the form of journals, articles, the legal basis of the engagement originating from an agreement where the act is contrary to the law and other materials that support this research;

- Documentary Studies, which is a method of collecting materials by examining government and non-government documents that support the above titles relating to Village-Owned Enterprises (VOBEA) in the Categorized Business as Legal Entities in Law Number 11 of 2020 concerning Job Creation.

\footnotetext{
${ }^{3}$ Johan Nasution Dan Bahder, 2008, Metode Penelitian IImu Hukum, Mandar Maju, Bandung.
} 
The analysis of legal materials in this study will use deductive logic analysis methods with qualitative normative analysis methods. Deductive logic analysis method is to draw conclusions from a general problem to the concrete problem under study. While the qualitative normative analysis method, namely the discussion and explanation that is arranged logically on the results of research on norms, rules, and legal theoretical foundations that are relevant to the subject matter.

\section{RESULTS AND DISCUSSION}

The Existence of Village Owned Enterprises (BUMDDes) as Legal Entities after the Enactment of Law Number 11 of 2020 concerning Job Creation. The status of Village-Owned Enterprises (VOBEA) as a business entity or legal entity is a problem and debate that often occurs in the community. This creates problems when VOBEA wants to cooperate with third parties or from the independence of VOBEA itself. ${ }^{4}$ Article 1 point 6 of Law Number 6 of 2014 concerning Villages (hereinafter referred to as the Village Law) states that VOBEA is a business entity whose capital is wholly or most of the capital owned by the village through direct participation from village assets which are separated to manage assets, services., and other efforts for the greatest welfare of the village community.

Historically, VOBEA was originally regulated as a legal entity. This can be seen in the explanation of Article 213 paragraph (2) of Law Number 32 of 2004 concerning Regional Government, namely Village-Owned Enterprises are legal entities as regulated in laws and regulations and reaffirmed in Article 78 paragraph (3) of Government Regulation Number 72 2005 concerning Villages, namely the Form of Village-Owned Enterprises as referred to in paragraph (1) must be a legal entity.

When viewed from the point of view of its juridical status, then the business entity can be distinguished into: (a) Business entities that are legal entities; and (b) Business entities that are not legal entities. Comparison in terms of advantages and disadvantages between legal entities and non-legal entities will be described as follows:

Table 1 - Advantages and Disadvantages between Legal Entities and Non-Legal Entities

\begin{tabular}{|l|l|l|}
\hline $\mathrm{n} / \mathrm{n}$ & Legal Entity & Business Entities that are Not Legal Entities \\
\hline 1 & $\begin{array}{l}\text { The legal subject here is the business entity itself, because it } \\
\text { has become a legal entity which is also a legal subject in } \\
\text { addition to humans. }\end{array}$ & $\begin{array}{l}\text { The legal subjects here are the people who are the } \\
\text { administrators, so they are not the business entity itself } \\
\text { because it is not a law so it cannot be a legal subject. }\end{array}$ \\
\hline 2 & $\begin{array}{l}\text { In this business entity, the company's assets are separated } \\
\text { from the personal assets of the management/members. As a } \\
\text { result, if the company goes bankrupt, only the company's } \\
\text { assets will be confiscated (personal assets of the } \\
\text { management/members remain free from confiscation). }\end{array}$ & $\begin{array}{l}\text { In this business entity, assets, company united with } \\
\text { property, personal management/members. As a result, } \\
\text { if the company goes bankrupt, the personal assets of } \\
\text { the management/members will also be confiscated in } \\
\text { addition to the company assets. }\end{array}$ \\
\hline 3 & $\begin{array}{l}\text { The forms of business entities that including legal entities, } \\
\text { among others: }\end{array}$ & - \\
- PT (Limited Liability Company) & PN (State Company) \\
- PD (Regional Company) & Cooperative \\
- Perum (General Company) & Perjan (Office Company) \\
- Persero (Sero Company) & Foundation and so on.
\end{tabular}

VOBEA is one of the economic institutions that is expected to be one that contributes to the source of village income. However, the existence of VOBEA needs to get a definite legal justification. One question that arises is: how to identify VOBEA as a legal entity? To be able to answer this, it must refer specifically to the Village Law and its implementing regulations, namely Government Regulation no. 43 year 2014 (PP Desa). In the Village Law and also PP Desa it is stated that Village-Owned Enterprises, hereinafter referred to as VOE,

\footnotetext{
${ }^{4}$ Alfiansyah, 2021, Status Badan Usaha Milik Desa Sebagai Badan Hukum Atas Diundangkannya Undang-Undang Cipta Kerja, Jurnal IImu Sosial Dan Pendidikan http://ejournal.mandalanursa.org/index.php/jisip/index, Vol. 5. No. 2 Maret 2021 P-Issn: 2598-9944 E- Issn: 2656-6753, HIm. 215.
} 
are business entities whose entire or most of the capital is owned by the Village through direct participation originating from Village assets which are separated to manage assets, services, and other efforts for the greatest welfare of the Village community. ${ }^{5}$

Furthermore, in Chapter X Article 87 of the Village Law, it is regulated that: (1) a village can establish a Village-Owned Enterprise called VOE; (2) VOE is managed in a spirit of kinship and mutual cooperation; (3) VOE can run a business in the economic sector and/or public services in accordance with the provisions of the laws and regulations.

In article 88 of the Village Law jo. Article 132 of the Village Regulation states that VOBEA is established based on a village meeting, which is then determined by a Village Regulation. Furthermore, in Article 135 of the Village Regulation it is stated that the initial VOBEA capital comes from the Village Budget which is the Village's wealth which is separated and is not divided into shares. VOBEA capital consists of: 1) Village Capital Participation, originating from the Village Budget and others; 2) Village Community Capital Participation. ${ }^{6}$

Unlike legal entities such as Limited Liability Companies, Foundations or Cooperatives, all of which get their status as legal entities when they get approval from the relevant minister. In the Village Law and Village Regulations it is not explicitly stated when VOBEA is legal to become a legal entity. However, from Article 88 of the Village Law jo. Article 132 of the Village Government Regulation which states that "The establishment of VOE is carried out through village meetings and determined by Village regulations" it can be concluded that when the agreement has been ratified in the Village meeting and the agreement is stipulated in a Village Regulation, then at that time VOBEA has been born as a legal entity.

Characteristically, VOBEA can be categorized as a legal entity because it has fulfilled the following characteristics:

- There are separate assets. Article 135 paragraph (3) of the Government Regulation of the Republic of Indonesia Number 47 of 2015 concerning Amendments to Government Regulation Number 43 of 2014 states that VOBEA assets sourced from village capital participation are village assets that are separated;

- Have a specific purpose. The explanation of Article 87 paragraph (1) of the Village Law states that VOBEA was formed to utilize all economic potential, economic institutions, as well as the potential of natural resources and human resources in order to improve the welfare of rural communities;

- Have own interests. The importance of VOBEA is also contained in the Elucidation of Article 87 paragraph (1) of the Village Law which states that VOBEA is oriented to financial gain and supports improving community welfare;

- There is a regular organization. The VOBEA organization is separate from the village government organization and the VOBEA organization consists at least of advisors and operational implementers. This provision is regulated in Article 132 paragraph (3) and (4) of Government Regulation of the Republic of Indonesia Number 43 of 2014.

After the enactment of the Village Law, the form of the VOBEA business entity changed. In Article 1 point 6 of the Village Law, it is stated that VOBEA is a business entity and in its explanation in Article 87 paragraph (1) VOBEa is a business entity characterized by a village which specifically cannot be equated with legal entities such as limited liability companies, CV or cooperatives. As for what makes VOBEA a new form of legal entity. In contrast to SOES and BUMD, which in the laws and regulations have clearly regulated, they can be in the form of a limited liability company or a public company. ${ }^{7}$ Therefore, VOBEA is a business entity characterized by a Village which in carrying out its activities in addition to assisting the administration of Village Government, also to meet the needs of the Village community. Thus, the noble purpose of the presence of VOBEA is intended to carry out the functions of services, trade, and other economic development.

\footnotetext{
${ }^{5}$ Erni Herawati, 2016, Badan Usaha Milik Desa, Status Dan Pembentukannya, https://businesslaw.binus.ac.id/2016/10/16/badan-usaha-milik-desa-status-dan-pembentukannyal, (diakses pada tanggal 3 Oktober 2021). ${ }^{6} \mathrm{Ibid}$

${ }^{7}$ Alfiansyah, Op.Cit, hlm.216.
} 
Therefore, VOBEA is a business entity characterized by a Village which in carrying out its activities in addition to assisting the administration of Village Government, also to meet the needs of the Village community. Thus, the noble purpose of the presence of VOBEA is intended to carry out the functions of services, trade, and other economic development:

"Village-Owned Enterprises, hereinafter referred to as VOBEA, are legal entities established by villages and/or together with villages to manage businesses, utilize assets, develop investment and productivity, provide services, and/or provide other types of businesses for the maximum amount of time. the magnitude of the welfare of the village community"

Based on the provisions stipulated in Article 117 of the Job Creation Law, as described above, the researcher will comprehensively describe the philosophical, sociological and juridical foundations regarding the status of VOBEA legal entities after the enactment of the Job Creation Act, as follows.

Philosophically, the enactment of the Job Creation Law is based on Article 4, Article 5 paragraph (1), Article 18, Article 18A, Article 18B, Article 20, Article 22D paragraph (2), Article 27 paragraph (2), Article 28D paragraph (1) and paragraph (2), and Article 33 of the 1945 Constitution of the Republic of Indonesia. Efforts to create work through efforts to facilitate, protect, and empower cooperatives and micro, small and medium enterprises, increase the investment ecosystem and ease of doing business, and Central Government investment and acceleration of national strategic projects.

Juridically, the background regarding the purpose of the enactment of the Job Creation Law is as stated in its preamble. The job creation law is expected to be able to absorb Indonesian workers who in the midst of increasingly competitive competition and the demands of economic globalization. Arrangements relating to the convenience, protection, and empowerment of cooperatives and micro, small and medium enterprises medium-sized enterprises, improving the investment ecosystem, and accelerating national strategic projects, including improving the protection and welfare of workers spread across various sectoral laws, currently cannot meet the legal requirements for accelerating job creation, so changes need to be made.

Sociologically, elucidation of Article 117 paragraph (1) of the Job Creation Law which amends the provisions in Article 87 of the Village Law explains that VOE is formed by the Village Government to utilize all economic potential, economic institutions, as well as the potential of natural resources and human resources are expected to improve the welfare of the Village community.

In increasing village income sources, VOBEA is expected to be able to collect savings on a local scale from the village community, including through the management of revolving funds and savings and loans. VOE in its activities is not only oriented towards financial gain, but also oriented towards supporting the improvement of the welfare of the Village community. In this case, business activities can be made possible when VOE follows a legal entity that has been stipulated in the provisions of the legislation.

Status of Legal Entities after the Enactment of Law Number 11 of 2020 concerning Job Creation in Performing the Functions of Public Legal Entities and Private Legal Entities. The concept of genossenschaft which is echoed by Otto Von Gierke as a German legal philosopher is understood as a legal entity concept that is relevant beyond the debate about gemeinschaft and gesellschaft. This concept is equivalent to a joint effort based on the principle of kinship. In addition, the genossenschaft contains village consultations. Specifically, genossenschaft is synonymous with village cooperatives, which are then mobilized by economic cooperatives (not cooperatives as legal entities) towards Indonesian socialism as echoed by Mohammad Hatta. Ir. SOEskarno dynamics the kinship with mutual cooperation, inspired by the Minangkabau nagari as an example of the basis of national identity (not just based on gesellschaft). Simply put, Gierke conveys an understanding of 
legal entities based on the principles of kinship, cooperation, deliberation and mutual cooperation. For convenience, we call it the term Integrated Legal Entity. ${ }^{8}$

In the theory of legal discourse, legal entity integration cannot be separated from the practice of communication between the state and citizens. The principle of recognition and subsidiarity in the Village Law is the result of the formation of opinions and aspirations in the political system. The village is understood as an integrated legal entity in which there are local self-government organizations and self-governing community organizations. ${ }^{9}$

In principle, legal entities can be divided into private legal entities and public legal entities. According to Chidir Ali, to determine whether a legal entity is a public legal entity or a private legal entity, 3 (criteria) can be used, namely the way in which it was established or occurred, its working environment and authority. ${ }^{10}$

The criteria for the method of establishment are to identify whether the legal entity was established under public law, that is, it was established by the authorities based on statutory regulations. The criteria for the work environment are to identify whether the legal entity established has committed acts within the civil law environment with the same status as other legal subjects. If not, then the legal entity can be classified as a legal entity. Public law. While the criteria for authority is to identify whether the legal entity established is given the authority to make decisions, statutes or general binding regulations. If so, then the legal entity can be classified as a public legal entity.

Peter Mahmud Marzuki ${ }^{11}$ states that a public legal entity is a state and parts of the country such as a city area and others, while a legal entity is a legal entity Private is an organization that operates outside the political and state fields, private legal entities are established for profit or for social purposes. Taking into account the opinion of Peter Mahmud Marzuki that the criteria used to distinguish public legal entities and private legal entities are still general in nature, this distinction has not answered questions such as what happens if the state or part of the state establishes or participates in organizations outside the state organization for the purpose of like for profit.

Furthermore, for business entities established by the state such as SOESs. According to Marzuki, the classification is based on the purpose of its establishment. For SOESs that are established in the context of public services, they are classified as a public legal entity and SOESs that are non-profit or for-profit are classified as private legal entities.

The public-private dichotomy with the criteria set by Peter Mahmud Marzuki is difficult to apply because in general companies such as SOES/VOE are established with multiple objectives, namely to carry out public service functions and seek profit as well as SOES/BUMD in the form of private legal entities (PT) although profit-oriented. However, it can be mandated to carry out a public service obligation (PSO) by the government/local government. While SOES/BUMD are in the form of public legal entities (public/regional companies), although their main orientation is public service, they also pursue profit and are managed professionally in accordance with the principles of good corporate governance like private companies in general. Likewise, VOE is not only commercially oriented but also includes social aspects.

When analyzed comprehensively, the operational definition of VOE in the Job Creation Act excludes or deletes the phrase "which all or most of the capital is owned by the Village through direct participation originating from the separated Village assets".

The logical consequence of this change is that it eliminates ownership criteria and opens up opportunities for private equity participation in VOE. Furthermore, the amendment to the Limited Liability Company Law in the Job Creation Law gives rise to the interpretation that VOBEa can be established in the form or made into a Limited Liability Company according to Article 109 paragraph (2) of the Job Creation Law which amends Article 7 of the

\footnotetext{
${ }^{8}$ Anom Surya Putra, 2018, "Memperjuangkan Badan Hukum Publik BUM Desa", https://www.berdesa.com/memperjuangkanbadan-hukum-publik-bum-desal, (diakses pada tanggal 3 Okrober 2021).

${ }^{10}$ Chidir Ali, 1985, Badan Hukum, Bandung: Alumni, hlm.62.

${ }^{11}$ Peter Mahmud Marzuki, 2008, Pengantar Ilmu Hukum, (Jakarta: Kencana Prana Media Group), hlm207.
} 
Company Law Article 7 paragraph (7) of the Company Law after the enactment of the Job Creation Law, reads as follows: ${ }^{12}$

"Provisions that require the Company to be established by 2 (two) or more people as referred to in paragraph (1), paragraph (5), and paragraph (6) does not apply to:

- Whose shares are wholly owned by the state;

- Regional owned enterprises;

- Village Owned Enterprises;

- Companies that manage stock exchanges, clearing and guarantee institutions, depository and settlement institutions, and other institutions in accordance with Capital Market Laws; or Companies that meet the criteria for Micro and Small Enterprises".

According to Detania, et al in their article on "Critical Study of Legal Entity Status and Basic Concepts of Village-Owned Enterprises" based on the VOBEa interpretation, it can be established in the form or made into a PT according to Article 109 paragraph (2) of the Job Creation Law which amends Article 7 of the Company Law Article 7 paragraph (7) of the Limited Liability Company Law after the enactment of the Employment Copyright Law actually confirms that VOE is a public legal entity because it was established based on the Perdes as stipulated by law. However, this will lead to overlapping settings if it is established in the form of a PT, then VOE becomes a private legal entity. This, of course, is increasingly contrary to the spirit of VOBEa as a business entity characterized by a Village which cannot be equated with cooperatives and PT as stated in the Village Law and is also mentioned again in the explanation section of the Job Creation Law. In other words, changes in the legal aspects of VOBEA in the Job Creation Law still carry an inconsistency of reasoning regarding the basic conception of VOBEA.

This inconsistency of reasoning is realistically faced by VOE in various ways, including the following: ${ }^{13}$

First, VOBEa as a legal entity seems to use a nominee arrangement (borrow name) to form a partnership. However, this can have implications for a number of legal issues such as taxation. Another alternative used by VOE is to make a Notary Deed of Establishment of VOE, which lists the names of the administrators as founders, and there is also the name of the Village Head, the names of the administrators as the founder and legal owner of VOE dispelled the concept of communal ownership in VOE.

It also doesn't include the name of the village head in the deed of establishment in line with laws and regulations that do not require a Notary Deed to establish VOE Establishment of a business entity with a Notary Deed is a characteristic of private business entities such as CV, PT or cooperative This is of course contrary to the VOE concept promoted by the Village Law.

When examined further, in Article 135 paragraph (2) of PP 43/2014 it is stated that VOE assets are village assets which are separated and not divided into shares. omitted This is allegedly because the phrase is not in sync with the Joint VOE concept established by 2 (two) or more VOEs. However, this is still contradictory. Even though it is not in the form of a PT, the share or amount of capital taken by each village is basically a shareholding concept which is no different from the concept of PT or CV, and the portion of responsibility of each village is according to the amount of capital.

Second, the phrase "it is very possible in time." in the explanation of the Village Law invites the understanding that there is a pause before the time comes when VOE can obtain status as a legal entity. However, there is ambiguity

when the status will be obtained, based on whose judgment and basis

which law will give the legal entity status (current normative law or other legal umbrella that will replace or revise it in the future). This wide-open space of interpretation also does not provide an explanation of whether the opportunity to increase VOE to become a legal

\footnotetext{
${ }^{12}$ Detania Sukarja, dkk, 2020, "Junal Arena Hukum: Telaah Kritis Status Badan Hukum Dan Konsep Dasar Badan Usaha Milik Desa", Volume 13, Nomor 3, Desember 2020 (diakses pada tanggal 3 Oktober 2021), hlm. 584.

${ }^{13} \mathrm{lbid}, \mathrm{hlm}$. 578-590.
} 
entity will be the domain of the authority of the Village or the central government and legislators who will set the normative boundaries.

Third, the phrase ".VOE follows a legal entity that has been stipulated in the provisions of the legislation." in the explanation of the Village Law gives rise to an interpretation that the form of a legal entity will follow the forms of existing legal entities, such as PT and cooperative If so, this is certainly the opposite of the previous part already mentioned that VOE is not the same as PT or cooperative which is a private legal entity. As previously mentioned the law seems to construct VOBEa as a unique business entity and has the special characteristics of the Village.

According to the author, the inconsistency of reasoning referred to by Detania, et al in their article on the "Critical Study of the Status of Legal Entities and Basic Concepts of Village Owned Enterprises" does not need to be debated at the conceptual level. Instead, we need to examine holistically regarding the construction of VOBEa as a unique business entity and has special characteristics of the village. Thus, VOBEa can be classified as a legal entity with public function.

For example, to broaden the perspective of drafters of legal regulations, we need to learn from VOE Tirta Mandiri, Ponggok Village, Klaten, as a reference for public BH. The Village Government, VOE Tirta Mandiri and the Ponggok Village community carried out a collective action governing the common over the Umbul water and other resources. The collective action developed dynamically through shareholding (sharing social capital, money capital and profit sharing), through 8 (eight) PTs formed by VOE Tirta Mandiri. Thus, VOBEa Tirta Mandiri is domiciled as a public legal entity that carries out public and private legal functions.

Let's look at Article 87 paragraph (1) and paragraph (2) of the Village Law and their full explanation. The Village Government establishes a VOE. It is inevitable that the Village Government must be interpreted as a certain Legal Subject. According to Himawan Estu Bagijo (2014) based on the decision of the Constitutional Court, it has determined the legal standing of public legal entities and private legal entities.

The normative prerequisites of a public legal entity are stipulated by laws and regulations, carrying out rights and obligations, owning wealth, and being able to sue and be sued in court. With the legal logic of adjudication of the Constitutional Court, the Village Government determined attributively is categorized as a public legal entity.

VOBEa is formed by the Village Government through a deliberation process, the Village assets/assets are separated, and specifically cannot be equated with legal entities such as PT, CV or cooperatives. The antithesis is that VOE is interpreted as a Legal Subject other than a private BH (PT, CV, Cooperative). Himawan's opinion upfront became the argument that VOE is a functional public BH formed by the Village Government based on the Village Law, followed by the Village Regulation on VOE, the Village Head's Decree on AD/ART and the management of VOE. Its position is equivalent to the validity of a notarial deed. No need to mix up the Village Head and Notary.

VOBEa runs a business in the field of economy and/or public services. Inevitably, VOBEa must adapt to enter into a liberal legal discourse that divides the functions of public law and private law. On the one hand, VOBEa carries out public legal functions to utilize all the economic potential of the village. On the other hand, VOBEa carries out private functions such as services, trade, and other economic development. This is where a fundamental change in understanding occurs. VOBEa as a functional public legal entity carries out both public and private legal functions.

\section{CONCLUSION}

The existence of Village-Owned Enterprises (BUMDes) as Legal Entities After the enactment of Law Number 11 of 2020 concerning Job Creation has provided clarity and affirmation of the legal entity status of VOBEa Article 117 of the Job Creation Law amends the provisions of Article 1 point 6 of the Village Law, which explicitly stated that "VillageOwned Enterprises, hereinafter referred to as VOBEa, are legal entities established by 
villages and/or with villages to manage businesses, utilize assets, develop investment and productivity, provide services, and/or provide other types of services. other efforts for the maximum welfare of the Village community. The clarity of VOE's position as a legal entity emphasizes the separation of Village assets from business entity assets. In the realm of business law, this separation is important to provide autonomy for the management to manage VOBEa professionally and to clarify the line of responsibility of the Village as the owner of separated assets.

Status of Legal Entities After the Enactment of Law Number 11 of 2020 concerning Job Creation in Performing the Functions of Public Legal Entities and Private Legal Entities implicitly means that the construction of VOBEa as a unique business entity and has special characteristics of the Village. Thus, VOBEa can be classified as a legal entity with a public function, namely VOBEa as a functional public legal entity that carries out both public and private legal functions.

\section{SUGGESTIONS}

Implementing regulations related to VOBEA are expected to be socialized properly and evenly so that the purpose of affirming the legal entity status of VOBEA can be achieved. VOBEA can facilitate in terms of ratifying as a legal entity so that it can act as rechtpersoon.

The confirmation of the legal entity status of VOBEa should be followed by correcting the inconsistency of reasoning regarding the basic concept of VOE as a public legal entity and a business entity characterized by a village which cannot be equated with private legal entities such as cooperatives and PT. In addition, synchronization has not been carried out with Law 15 of 2019 concerning the hierarchy of the formation of statutory regulations and various other sectoral UNs that are not familiar with the VOE nomenclature as a variant of the form of a business entity. This can have implications for the difficulty of VOBEa being accepted as a legal entity in practice.

\section{REFERENCES}

1. Chidir Ali, 2005, Badan Hukum, Alumni, Bandung: Alumni.

2. Johan Nasution dan Bahder, 2008, Metode Penelitian IImu Hukum, Mandar Maju, Bandung.

3. Peter Mahmud Marzuki, 2008, Pengantar Ilmu Hukum, (Jakarta: Kencana Prana Media Group).

4. Riduan Syahrani, 1999, Seluk Beluk dan Asas-Asas Hukum Perdata, Bandung.

5. Ronny Hanitijo SOEsmitro, 1988, Metode Penelitian Hukum dan Jurimetri, Jakarta, Alumni.

6. Achmad Fauzi, 2017, Tata Kelola Dana Desa Dalam Rangka Implementasi UndangUndang Nomor 6 Tahun 2014 Tentang Desa Di Kabupaten Sidoarjo, Jurnal: Kebijakan Dan Manajemen Publik), 5 (1), 23-40issn 2338-445x(Print), Issn 2527-9246 http://ojs.umsida.ac.id/index.php/jkmp (Diakses Pada Tanggal 25 Maret2021)

7. Alfiansyah, 2021, Status Badan Usaha Milik Desa Sebagai Badan Hukum Atas Diundangkannya Undang-Undang Cipta Kerja, Jurnal IImu Sosial dan Pendidikan http://ejournal.mandalanursa.org/index.php/JISIP/index, Vol. 5. No. 2 Maret 2021 p-ISSN: 2598-9944 e- ISSN: 2656-6753.

8. Anom Surya Putra, Ketua Umum Perkumpulan Jaringan Komunikasi (Jarkom) Desa, "VOBEa Bukan Badan Hukum Privat", https://www.desapedia.id/VOBEa-bukan-badanhukum-privat/, (diakses pada tanggal 8 Juli 2021).

9. Detania Sukarja, dkk, 2020, "Junal Arena Hukum: Telaah Kritis Status Badan Hukum Dan Konsep Dasar Badan Usaha Milik Desa", Volume 13, Nomor 3, Desember 2020 (diakses pada tanggal 3 Oktober 2021).

10. Erni Herawati, 2016, Badan Usaha Milik Desa, Status Dan Pembentukannya, https://business-law.binus.ac.id/2016/10/16/badan-usaha-milik-desa-status-danpembentukannya/, (diakses pada tanggal 3 Oktober 2021). 
11. Undang-Undang No. 6 Tahun 2014 Tentang Desa.

12. Undang-Undang Nomor 32 Tahun 2004 tentang Pemerintah Daerah.

13. Undang-Undang Nomor 11 Tahun 2020 Tentang Cipta Kerja

14. Peraturan Pemerintah Nomor 72 Tahun 2005 tentang Desa.

15. Peraturan Pemerintah Nomor 11 Tahun 2021 tentang VOBEA.

16. VOBEAid, 2018, "Bedah Hukum VOBEa: Menegaskan Kembali Badan Hukum VOBEA", https://VOBEA.id/2018/11/bedah-buku-VOBEa-menegaskan-kembali-badan-hukumVOBEA/, diakses 30 Agustus 2021.

17. Detik News, "Tingkatkan Perekonomian Desa, 74 Ribu Desa Bakal Terima Dana Rp 1,4 Miliar", www.news.detik.com diakses pada 26 Maret 2021.

18. Harian Kompas, "Jumlah VOBEA Mencapai 18.446 Unit", www.ekonomi.kompas.com diakses pada 27 Maret 2021. 